\title{
4. PETROMAGNETIC STUDY OF IGNEOUS ROCKS OF THE TAITAO RIDGE, CHILE TRIPLE JUNCTION, SITE $862^{1}$
}

\author{
Alexei N. Didenko ${ }^{2}$ and Randall Forsythe ${ }^{3}$
}

\begin{abstract}
This paper reports and discusses the petromagnetic (i.e., rock magnetic) properties and chemical compositions of titanomagnetites occurring within a bimodal suite of late Pliocene volcanic rocks obtained from the Taitao Ridge, at Site 862 in the Chile Triple Junction region. The results indicate a marked contrast in magmatic sources, as well as in the cooling and alteration histories for the silicic and basaltic lavas. Basaltic units have petromagnetic and chemical characteristics generally consistent with a mid-ocean ridge basalt (MORB) affinity, and show systematic differences that correlate with the texturally-inferred cooling and alteration histories. Magnetic phases in the silicic lavas are similar to those reported from calc-alkaline circum-Pacific suites. The secondary alteration of the titanomagnetites within the silicic units is much less than that observed within the basaltic lavas, in which titanomagnetite has been altered to titanomaghemite.

Given the elevated forearc geothermal gradients encountered in the Triple Junction Chile Margin region, the calculated Curie points for observed ferrimagnetic phases in the basalts, and that titanomaghemite is the dominant magnetic carrier, it is highly probable that young oceanic crust near the triple junction is quickly remagnetized when underthrust along the toe of the continental forearc.
\end{abstract}

\section{INTRODUCTION}

Leg 141 of the Ocean Drilling Program (ODP) drilled the western continental slope of southern South America within the region of the Chile Triple Junction $\left(46^{\circ} 30^{\prime} \mathrm{S}\right)$. The objective of Leg 141 was an investigation of the thermal and tectonic consequences of the collision of a segment of the Chile Rise spreading ridge with the continental margin between the Taitao and Darwin Fracture Zones. Initial drilling targets included basaltic crust that was likely to be present at depth at Sites 859 and 862 . Volcanic units were only penetrated and recovered at Site 862. Pre-cruise seismic analysis underestimated the depth to basement at Site 859, because actual seismic velocities of the lower slope sediments were higher than expected; hence, although drilling at this site extended to planned sub-bottom depths, basement was not reached.

Site 862 is located on an anomalous bathymetric ridge (Taitao Ridge) that juts out from the continental slope along the landward extension of the Taitao Fracture Zone (Fig. 1). Marine geophysical data, particularly marine magnetic anomalies, suggest that the Taitao Ridge is underlain by oceanic crust (Berhmann, Lewis, Musgrave, et al., 1993). Uplifted and exposed along the coast directly to the southeast of the Taitao Ridge are late Pliocene near-trench magmatic rocks that include the Taitao ophiolite (Forsythe et al., 1986). This ophiolite body, as well as nearby granophyric plutons and stockworks, are believed to have been produced during the collision of two ridge segments (bounded by the Esmeralda, Tres Montes, and Taitao Fracture Zones) from 6 to 4.5 and 2.5 to $3.5 \mathrm{Ma}$. (Nelson et al., 1994). Issues initially to be addressed by drilling at Site 862 included the age, composition, structure, and origin of the Taitao Ridge. However, independently of these issues, recovery of the basaltic units from the Taitao Ridge also provides an important opportunity to investigate directly the manner in which "normal" MORB processes may be affected by the process of ridge collision.

\footnotetext{
'Lewis, S.D., Behrmann, J.H., Musgrave, R.J., and Cande, S.C. (Eds.), 1995. Proc. ODP, Sci. Results, 141: College Station, TX (Ocean Drilling Program).

${ }^{2}$ Institute of Physics of the Earth, Academy of Sciences, Bolshaya Gruzinskaya 10 , Moscow, 12810, Russia.

${ }^{3}$ Department of Geography and Earth Sciences, University of North Carolina, Charlotte, NC 28223, U.S.A.
}

Here we report on a petromagnetic investigation of the volcanic samples obtained from the Taitao Ridge. Rock magnetic investigations of the titanomagnetite and titanohematite series which are common in unaltered and altered lavas can provide important information on the conditions of origin of magnetic mineral phases, as well as on their subsequent thermal and chemical histories. Of particular interest in this petromagnetic investigation are potential comparisons that can be drawn between the Taitao Ridge phyric basalts and the general magnetic characteristics of MORB basalts, as well as between the basaltic and silicic units recovered from Site 862 .

\section{SAMPLE SUITE AND RELATED WORK}

Drilling at Holes 862A, 862B, and 862C (Fig. 1) recovered 104 unoriented fragments of phyric basalt, phyric dacite, rhyodacite, and rhyolite. The units constitute a bimodal suite of volcanic units of enigmatic origin. Approximately 30 subsamples were taken from these 104 fragments and used for this rock-magnetic investigation. Shipboard XRF analyses of some of these units (Berhmann et al., 1993), and other results reported by Forsythe et al. (this volume), and Kurnosov et al. (this volume), document major and minor element whole-rock and glass compositions. Kurnosov et al. (this volume), also compare the secondary alteration mineralogy of the recovered basalts from the Taitao Ridge and a suite of basalts from the on-shore Taitao ophiolite.

\section{PETROGRAPHIC AND GEOCHEMICAL FEATURES OF SITE 862 VOLCANIC ROCKS}

Igneous rocks at Site 862 may be divided into two main categories. The first is composed of silicic volcanics ranging in composition from dacite to rhyolite. The second category comprises phyric basalts.

Most of the dacite to rhyolite samples are similar in petrographic character. They are characterized by dispersed and glomerophyric clusters of phenocrysts enclosed within a pilotaxitic matrix. The phenocrysts include: plagioclase (up to $1.6 \mathrm{~mm}$ size), hornblende $(0.7$ $\mathrm{mm}$ ), orthopyroxene $(0.7 \mathrm{~mm}$ ) and opaque minerals (up to $0.01 \mathrm{~mm}$ ). The pilotaxitic matrix contains much finer crystals of plagioclase $(50 \%)$, glass $(48 \%)$, and finely dispersed opaque minerals. Individual crystals of zircon were also found in a few samples. Electron microscopy and microprobe analyses indicate that the opaque minerals are grains of titanomagnetite (both euhedral and anhedral) and ilmenite 

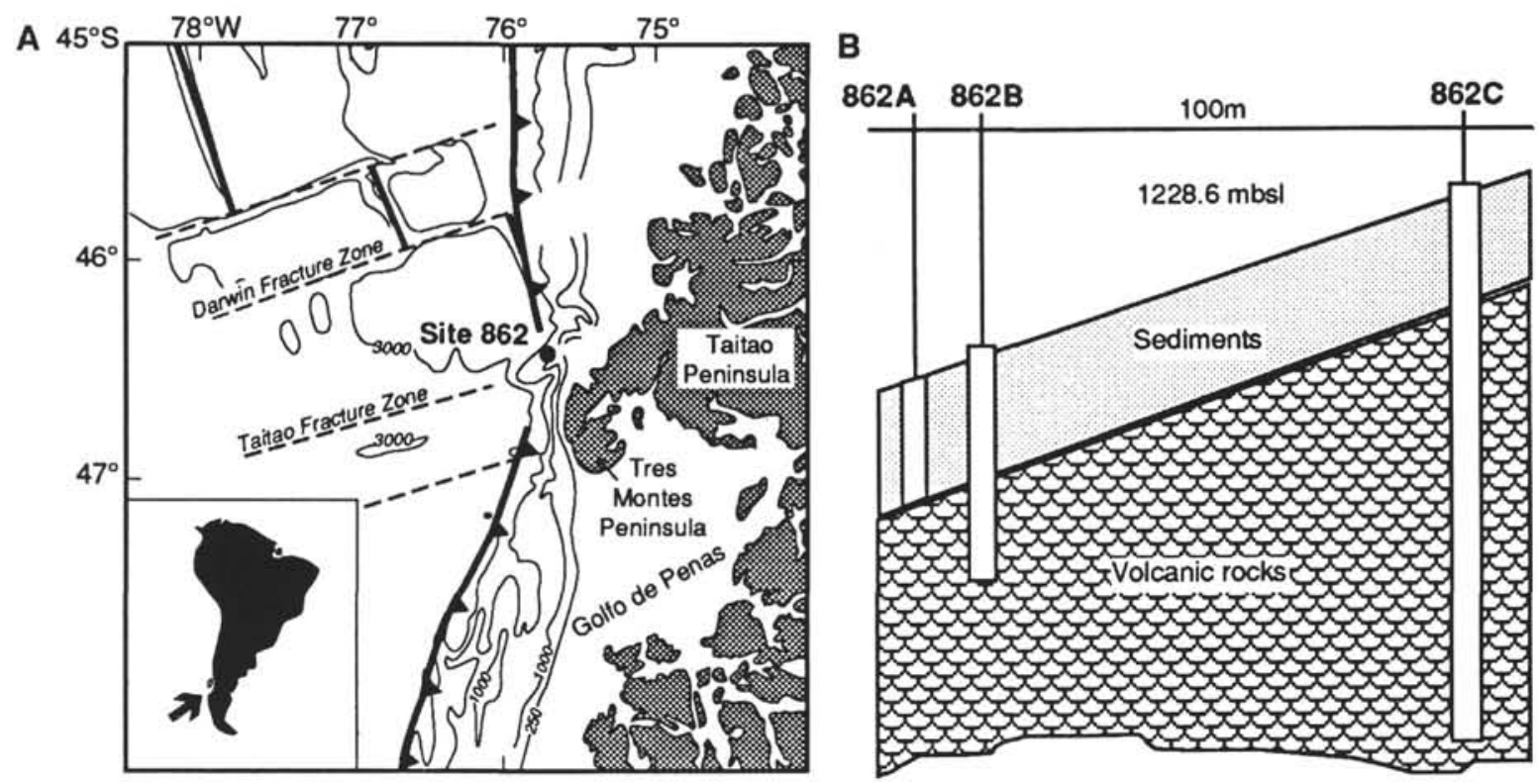

Figure 1. A. Location map showing the position of Site 862, the Taitao Peninsula and the Taitao Fracture Zone. B. Profile of the Taitao Ridge along the line of the three holes drilled at Site 862 .

ranging up to $0.1 \mathrm{~mm}$ in size. Two rounded ilmenite grains were identified in a plagioclase phenocryst of Sample 141-862B-1W-1, Piece 2.

The phyric basalts are subdivided into two groups for the purposes of our discussion.

The first group (Group 1) is composed of relatively unaltered plagioclase-phyric basalts with subophitic textures. These basalts contain isolated early plagioclase $(1.5 \mathrm{~mm})$ and olivine $(1.5 \mathrm{~mm})$ phenocrysts, smaller laths of plagioclase $(0.3 \mathrm{~mm})$, aggregates of monoclinal pyroxene $(0.03 \mathrm{~mm})$, devitrified glass, and small grains of opaque minerals (altered titanomagnetite [see discussion below] and ilmenite, up to $0.005 \mathrm{~mm}$ ).

The second group (Group 2), which includes the majority of the basaltic samples, comprises equigranular vesicular phyric basalts that lack the obvious isolated larger phenocrysts of Group 1 basalts. Basalts of Group 2 are composed of plagioclase ( $50 \%$; size $\leq 0.3 \mathrm{~mm}$ ), olivine $(15 \%$, size $\leq 0.15 \mathrm{~mm})$, clinopyroxene $(10 \%$; size $\leq 0.15 \mathrm{~mm})$, vesicules ( $24 \%$; whose walls are covered by yellowish-brown smectites), and opaque minerals ( $1 \%$ ) that are largely represented by altered titanomagnetite.

The two groups are transitional and the assignment of individual samples is based on the visual and relative comparisons of textures. For example, Sample 141-862B-4X-2, Piece 4, which was assigned to Group 1 on the basis of its subophitic texture, also contains numerous vesicles. The transitional characteristics are likely reflective of the differential cooling histories of individual flows or pillows. Group 2 samples represent the more slowly cooled interiors of the flows (or pillows) and Group 1 samples represent the margins of these units.

The opaque phases in both groups of basalts consist of altered titanomagnetites (oxidized to titanomaghemite, see below) and ilmenites. There are two generations of oxidized titanomagnetites within both groups of phyric basalt. Skeletal dendro- and isometricallyshaped oxidized titanomagnetites up to $0.001 \mathrm{~mm}$ in size occur throughout most samples, and there are dispersed, sub-micron, grains of oxidized titanomagnetites within the matrix. Rare ilmenites are present as stubby plates up to $0.3 \mathrm{~mm}$ in length.

Shipboard XRF analyses (Berhmann, et al., 1993), and 14 additional analyses conducted as part of this study (Table 1), indicate the presence of two major compositional types. These are the silicic rocks, with wt $\% \mathrm{SiO}_{2}$ from $64 \%$ to $69 \%$, and the basaltic rocks with wt $\% \mathrm{SiO}_{2}$ from $48 \%$ to $51 \%$. Shipboard macro- and microscopic rock descriptions mention the presence of some secondary minerals within the basaltic rocks. However, these secondary phases are present in only minor proportions, and do not represent a significant change in the bulk chemical compositions of the basalts. The compositional data lie within the area for unaltered basalts when plotted in the log $\left(\mathrm{Na}_{2} \mathrm{O} / \mathrm{K}_{2} \mathrm{O}\right)-\mathrm{Na}_{2} \mathrm{O}+\mathrm{K}_{2} \mathrm{O}$ diagram of Miyashiro (1975). Consistent with a low alteration state is the low calculated-water contents in the samples.

On an AFM diagram (Fig. 2a), the 14 samples analyzed after the cruise fall within the calk-alkaline field and lie close to compositions of igneous rocks found within the continent-ocean convergent margins of the western Pacific (Ewart, 1982). The calk-alkaline nature of this suite and its similarity to the circum-Pacific calc-alkaline suites (Sayfert, 1991) is also indicated by the $\mathrm{K}_{2} \mathrm{O}-\mathrm{SiO}_{2}$ diagram (Fig. 2b). However, an Fe-enrichment index (Miyashiro, 1975) discriminates between the basalts and silicic units from the Taitao Ridge (Fig. 2c); the silicic compositions are located in the calk-alkaline field, and basalts within the tholeiite field. Thus the suite of igneous samples recovered from the Taitao Ridge appear to be truly bimodal in character.

\section{ROCK MAGNETISM \\ Methods}

All magnetic measurements were made on cubic pieces with a volume of $1 \mathrm{~cm}^{3}$. Remanent magnetizations were measured with a JR-4 spinner magnetometer, and the initial magnetic susceptibilities (k) were measured with a Kappabridge KLY-2 susceptibility meter. Hysteresis loops were obtained using a vibrating sample magnetometer similar to that described by Kobayashi and Fuller (1967). The saturation magnetization $\left(\mathrm{J}_{\mathrm{s}}\right)$ and saturation remanence $\left(\mathrm{J}_{\mathrm{rs}}\right)$ were obtained from plots of the hysteresis loops. The remanent coercive force $\left(\mathrm{H}_{\mathrm{cr}}\right)$ was obtained from the direct field demagnetization of $\mathrm{J}_{\mathrm{rs}}$. Thermomagnetic curves were obtained using an oven-equipped vibrating sample magnetometer under an applied magnetic field of 300 mT. All thermomagnetic measurements were made in air; samples were heated to a maximum temperature of about $600-650^{\circ} \mathrm{C}$. The heating rate was $30^{\circ} \mathrm{C} / \mathrm{min}$. After the first heating cycle samples were cooled to room temperature, and the thermomagnetic cycle was then 

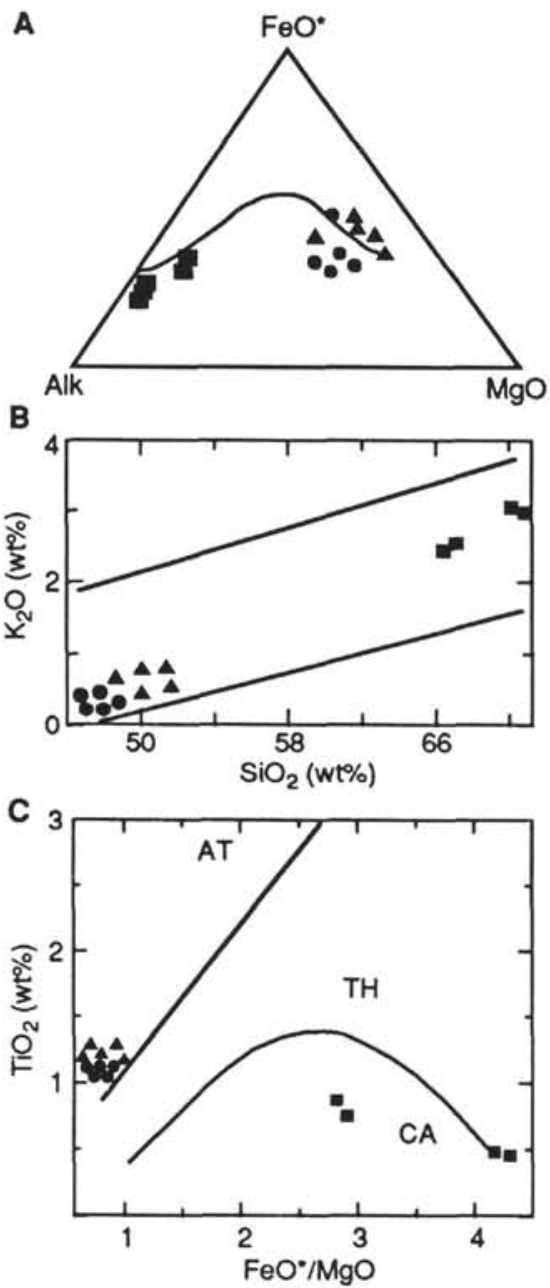

Figure 2. Petrochemical properties of magmatic rocks from Taitao ridge. A. AFM diagram. B. $\mathrm{K}_{2} \mathrm{O}$ vs. $\mathrm{SiO}_{2}$ diagram. C. Miyashiro (1975) diagram. Triangles $=$ Group 1 basalts (subophitic tecture), filled circles $=$ Group 2 (vesicular) basalts, squares $=$ dacites and rhyolites. $\mathrm{CA}=$ calk-alkaline, $\mathrm{TH}=$ tholeiitic, and $\mathrm{AT}=$ abyssal tholeiitic series.

repeated. Curie temperatures from these curves were determined using a simple graphic technique.

\section{Results}

The magnetic properties of samples obtained from Holes 862B and $862 \mathrm{C}$ permit grouping of samples into three sets (Table 2, Fig. 3 ). These parallel the petrographically-defined sets (silicic, basaltic Group 1, and basaltic Group 2) discussed above. Each of these sets have distinctive differences in magnetic properties such as natural remanent magnetization (NRM), magnetic susceptibility, and Königsberger ratio.

The silicic samples can be characterized magnetically by their relatively low NRM intensity $(<1 \mathrm{~A} / \mathrm{m})$, by their susceptibility, which is higher on average than for either basalt type, and by their Königsberger and $\mathrm{J}_{\mathrm{rs}} / \mathrm{J}_{\mathrm{s}}$ ratios, which are less than those of the basalts (Table 2). These characteristics of the silicic samples imply a remanent magnetization carried by multidomain titanomagnetites $\left(\mathrm{J}_{\mathrm{rs}} / \mathrm{J}_{\mathrm{s}}<\right.$ 0.06 ) with numerous additional smaller-grained, paramagnetic, $\mathrm{Fe}-\mathrm{Ti}$ minerals holding a purely inductive magnetic moment.

The distribution of silicic rocks in $\log (\mathrm{K})-\log \left(\mathrm{J}_{\mathrm{rs}}\right)$ space (Fig. 3a) differs sharply from that of the basalts. Thermomagnetic analysis of the silicic units indicates the presence of a carrier with a Curie point
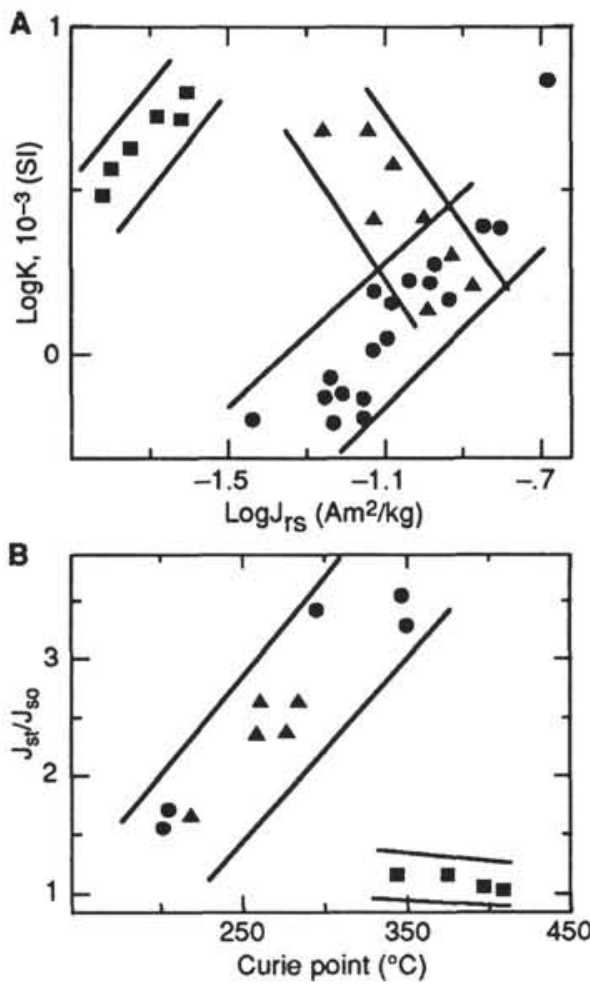

Figure 3. Petromagnetic properties of magmatic rocks from Taitao Ridge. A. K vs. $\mathrm{J}_{\mathrm{rs}}$, where $\mathrm{K}=$ initial magnetic susceptibility, and $\mathrm{J}_{\mathrm{rs}}=$ saturation remanent magnetization. B. $\mathrm{J}_{\mathrm{s}} / \mathrm{J}_{\mathrm{so}}$ vs. Curie point, where $\mathrm{J}_{\mathrm{so}}$ and $\mathrm{J}_{\mathrm{st}}=$ saturation magnetization before and after heating to $600^{\circ} \mathrm{C}$, respectively. For legend see Figure 2 .

between $340^{\circ}$ and $400^{\circ} \mathrm{C}$ (Fig. 4, Table 2). The $\mathrm{J}_{\mathrm{s}}-\mathrm{T}$ curve for a repeat heating run is very close to the curve for the initial heating, indicating that the thermally unstable oxidation product of titanomagnetite, titanomaghemite, is present in no more than very limited quantities.

In contrast, thermomagnetic analysis shows that the magnetic fraction within the basalts consists predominantly of titanomaghemite. This is indicated by the $\mathrm{J}_{\mathrm{s}}-\mathrm{T}$ behavior which typifies all the basalt samples (Fig. 4). An upward trend within the first heating curve (within the $400^{\circ}-520^{\circ} \mathrm{C}$ range) can be attributed to the formation of titanomagnetite following heating of titanomaghemite. The increased $\mathrm{J}_{\mathrm{s}}$ seen in the second thermomagnetic run results from the presence of this newly formed magnetite (Pechersky et al., 1978).

In addition to the first order differences that set silicic samples apart from the basalts, the basalts have distinctions that clearly separate Groups 1 and 2. For example, Group 1 basalts (the subophitic group), display a reverse $\mathrm{K}-\mathrm{J}_{\mathrm{rs}}$ correlation (Fig. 3a). Slow quenching rates implied by the subophitic texture would have promoted the growth of grains, so increasing magnetic susceptibilities and decreasing residual remanent magnetic moments as single or pseudosingle domain grains grew to multidomain size (Sholpo, 1976). Samples displaying this behavior include Samples 141-862B-4X-2, Piece 4, $-4 \mathrm{X}-2$, Piece $5,-4 \mathrm{X}-2$, Piece 12 , and $-4 \mathrm{X}-2$, Piece 13 . Group 2 basalts show a positive $\mathrm{K}-\mathrm{J}_{\mathrm{rs}}$ correlation (Fig. 3a). The behavior of this group is probably due to the fact that the exterior margins of the flows or pillows have a sufficiently rapid crystallization and cooling history to restrict titanomagnetite (and its alteration product, titanomaghemite) largely to the formation of single or pseudosingle domain grains, for which $\mathrm{J}_{\mathrm{rs}} / \mathrm{J}_{\mathrm{s}}>0.25-0.3$ (Table 2). This group includes Samples 141862B-3X-1, Piece 3,-3X-1, Piece 7,-3X-1, Piece 10,-3X-1, Piece 13, $-4 \mathrm{X}-2$, Piece 10 , and $-4 \mathrm{X}-2$, Piece 18.

On the $\mathrm{J}_{\mathrm{st}} / \mathrm{J}_{\mathrm{so}}-\mathrm{T}_{\mathrm{c}}$ diagram the Curie points for the ten basaltic samples form a well defined linear distribution with a positive correlation, and have a limited range from $210^{\circ}-350^{\circ} \mathrm{C}$ (Fig. 3b). This linear 
Table 1. Chemical composition of igneous samples from Holes 862B and 862C.

\begin{tabular}{|c|c|c|c|c|c|c|c|}
\hline Hole, core section: & $862 \mathrm{~B}-1 \mathrm{~W}-1$ & $862 B-4 X-1$ & $862 C-4 R-1$ & $862 C-5 R-1$ & $862 B-3 X-1$ & $862 B-3 X-1$ & $862 B-3 X-1$ \\
\hline Piece: & 2 & 1 & 3 & 3 & 1 & 10 & 13 \\
\hline $\mathrm{SiO}_{2}$ & 67.98 & 68.79 & 64.93 & 64.82 & 48.61 & 48.44 & 47.90 \\
\hline $\mathrm{TiO}_{2}^{-}$ & 0.56 & 0.56 & 0.80 & 0.88 & 1.20 & 1.10 & 1.15 \\
\hline $\mathrm{Al}_{2} \mathrm{O}_{3}$ & 14.57 & 14.24 & 15.28 & 15.38 & 17.04 & 17.12 & 16.99 \\
\hline $\mathrm{Fe}_{2} \mathrm{O}_{3}$ & 1.22 & 1.28 & 1.56 & 1.95 & 2.59 & 3.30 & 2.85 \\
\hline $\mathrm{FeO}$ & 1.39 & 1.31 & 2.47 & 2.25 & 5.88 & 5.20 & 5.86 \\
\hline $\mathrm{MnO}$ & 0.04 & 0.04 & 0.06 & 0.06 & 0.14 & 0.16 & 0.15 \\
\hline $\mathrm{MgO}$ & 0.59 & 0.59 & 1.36 & 1.44 & 9.04 & 5.39 & 8.85 \\
\hline $\mathrm{CaO}$ & 2.67 & 2.53 & 4.11 & 4.09 & 11.86 & 12.27 & 11.96 \\
\hline $\mathrm{Na}_{2} \mathrm{O}$ & 4.80 & 4.94 & 4.81 & 4.61 & 3.23 & 3.07 & 2.89 \\
\hline $\mathrm{K}, \mathrm{O}$ & 3.05 & 2.97 & 2.44 & 2.44 & 0.19 & 0.29 & 0.21 \\
\hline $\mathrm{P}_{1} \mathrm{O}_{5}$ & 0.08 & 0.08 & 0.12 & 0.13 & 0.10 & 0.10 & 0.09 \\
\hline $\mathrm{H}_{2} \mathrm{O}^{+}$ & 2.47 & 2.38 & 1.74 & 1.38 & 0.19 & 0.12 & 0.23 \\
\hline $\mathrm{H}^{2} \mathrm{O}^{-}$ & 0.20 & 0.41 & 0.12 & 0.11 & 0.32 & 0.47 & 0.25 \\
\hline Total & 99.62 & 100.12 & 99.80 & 99.54 & 100.39 & 100.20 & 99.38 \\
\hline Loss & 0.00 & 0.10 & 0.12 & 0.57 & 0.00 & 0.25 & 0.33 \\
\hline Hole, core. section: & $862 B-3 X-1$ & $862 B-3 X-1$ & $862 B-4 X-2$ & $862 B-4 X-2$ & $862 B-4 X-2$ & $862 B-4 X-2$ & $862 \mathrm{~B}-4 \mathrm{X}-2$ \\
\hline Piece: & 17 & 18 & 14 & 7 & 12 & 13 & 18 \\
\hline $\mathrm{SiO}_{2}$ & 48.53 & 48.52 & 50.13 & 50.66 & 50.44 & 49.36 & 50.14 \\
\hline $\mathrm{TiO}^{-}$ & 1.20 & 1.12 & 1.16 & 2.28 & 1.27 & 1.11 & 1.27 \\
\hline $\mathrm{Al}_{2} \mathrm{O}_{3}$ & 17.02 & 16.51 & 16.65 & 16.21 & 16.64 & 16.82 & 16.23 \\
\hline $\mathrm{Fe}=\mathrm{O}_{3}$ & 2.25 & 2.61 & 3.99 & 3.95 & 2.81 & 3.30 & 2.83 \\
\hline $\mathrm{FeO}$ & 6.32 & 6.01 & 4.18 & 4.67 & 4.87 & 4.10 & 4.72 \\
\hline $\mathrm{MnO}$ & 0.16 & 0.16 & 0.13 & 0.12 & 0.14 & 0.13 & 0.14 \\
\hline $\mathrm{MgO}$ & 9.01 & 8.59 & 830 & 8.03 & 8.56 & 9.14 & 8.75 \\
\hline $\mathrm{CaO}$ & 11.95 & 11.48 & 9.95 & 10.06 & 9.86 & 10.21 & 9.40 \\
\hline $\mathrm{Na}, \mathrm{O}$ & 2.89 & 4.34 & 3.52 & 3.52 & 3.62 & 3.43 & 4.43 \\
\hline $\mathrm{K}, \mathrm{O}$ & 0.19 & 0.23 & 0.57 & 0.69 & 0.77 & 0.53 & 0.71 \\
\hline $\mathrm{P}_{2} \mathrm{O}_{6}$ & 0.09 & 0.08 & 0.14 & 0.15 & 0.14 & 0.13 & 0.14 \\
\hline $\mathrm{H}, \mathrm{O}^{-}$ & 0.23 & 0.14 & 0.30 & 0.21 & 0.48 & 0.57 & 0.60 \\
\hline $\mathrm{H}, \mathrm{O}^{-}$ & 0.48 & 0.43 & 0.85 & 0.72 & 0.64 & 1.17 & 0.95 \\
\hline Total & 100.32 & 100.22 & 99.87 & 100.27 & 100.24 & 100.00 & 100.31 \\
\hline Loss & 0.25 & 0.10 & 0.47 & 0.20 & 0.20 & 0.30 & 0.20 \\
\hline
\end{tabular}

distribution of $\mathrm{J}_{\mathrm{st}} / \mathrm{J}_{\mathrm{so}}$ with $\mathrm{T}_{\mathrm{c}}$ is indicative of low temperature oxidation to titanomaghemite, which in turn has been found to be typical of submarine basalts (i.e., the higher the degree of low-temperature oxidation, the higher the Curie point and $\mathrm{J}_{\mathrm{st}} / \mathrm{J}_{\mathrm{so}}$ ratio; Pechersky et al., 1978). The distinct $J_{s t} / J_{s o}-T_{c}$ correlation enables us to estimate the Curie point for the primary, unaltered titanomagnetites of the basalts (Didenko and Tikhonov, 1991). For an assumed $\mathrm{J}_{\mathrm{s} /} / \mathrm{J}_{\mathrm{so}}=1$, the Curie point $\left(\mathrm{T}_{\mathrm{c}}\right)=170^{\circ}-190^{\circ} \mathrm{C}$ (Fig. 3b), which is in line with the Curie points calculated by the contents of $\mathrm{TiO}_{2}$ and $\mathrm{FeO}$ in the altered titanomagnetites (Table 3 ).

\section{MICROPROBE ANALYTIC DATA}

Chemical composition of ferromagnetic minerals was analyzed by a Camebax electron microprobe. The acceleration voltage was $15 \mathrm{kV}$ and the beam current on the Faraday cup was $20 \mathrm{nA}$. The true concentration of elements was calculated by correcting for atomic number, and absorption and fluorescence effects on the X-ray intensities.

The electron microprobe was used to analyze all microscopically identifiable opaque phases. However, analyses of the finer, submicron, opaque grains (grain radius excitation radius of electron beam) show increased, erroneous, concentrations of $\mathrm{SiO}_{2}, \mathrm{MgO}$, and possibly $\mathrm{Al}_{2} \mathrm{O}_{3}$ (Table 3). Analyses carried out on large grains $(5-10 \mu \mathrm{m})$, do not have this contamination. Figure 5 illustrates how $\mathrm{FeO} *$ and $\mathrm{TiO}_{2}$ concentrations (and their ratios) relate to $\mathrm{SiO}_{2}$. As can be seen, the larger grains display a distinct linear correlation. This implies that $\mathrm{Fe}$ and $\mathrm{Ti}$ were not withdrawn from titanomagnetite during secondary oxidation and alteration processes. Thus the $\mathrm{TiO}_{2} / \mathrm{FeO}^{*}$ ratios can be used to estimate primary igneous titanomagnetite compositions. The primary titanomagnetite phases contained in basalt and silicic samples have initial X ratios (ulvospinel-magnetite endmembers) of $0.58-0.70$ and $0.3-0.38$, respectively. Approximately the same parameters were obtained through using $\mathrm{TiO}_{2}$ concentrations for grains with less than $1 \mathrm{wt} \%$ $\mathrm{SiO}_{2}$. It is clear from inspection of the data that the compositional trends of the primary titanomagnetites are not continuous. On the contrary, two explicit groups may be distinguished. One has titanomag- netites with $X=0.3-0.38$ (dacite-rhyolites) and the other, titanomagnetites with $X=0.57-0.7$ (basalts).

The concentrations of $\mathrm{CuO}$ indicate one more substantial difference between the primary titanomagnetites of the silicic and basaltic groups. Within the titanomagnetites from silicic samples the $\mathrm{CuO}$ contents are practically zero ( $\leq$ detection limits), whereas in the titanomagnetites of basaltic samples the $\mathrm{CuO}$ concentrations are much higher. The combined $\mathrm{Ti}, \mathrm{Fe}$, and $\mathrm{Cu}$ cation distributions in titanomagnetites show distinct and sharp differences between the silicic and basaltic samples. This possibly reflects contrasting magmatic sources for these phases.

\section{DISCUSSION}

Consistent distinctions can be drawn between the silicic and basaltic volcanic units recovered from the Taitao Ridge from both the geochemical and petromagnetic data. While arguments have been made (Behrmann, Lewis, Musgrave, et al., 1992) that the two series are contemporaneous on the basis of their intermixed positions in the recovered cores from Holes $862 \mathrm{~B}$ and $862 \mathrm{C}$, geochemical and petromagnetic arguments, discussed further below, support distinct sources and histories for the two series.

First, the absence of intermediate products of a magmatic differentiation series within the rock suite leaves doubt over the existence of a differentiation series that might link the two compositional groups.

Second, the contrasts of original titanomagnetite compositions within the two compositional groups are inconsistent with a single magmatic source. The compositions of titanomagnetites observed within the basalts $(\mathrm{X}=0.57-0.65)$ corresponds closely to those reported from many MORB environs (Didenko, 1990; Pechersky, Tikhonov, 1983). The composition of titanomagnetites within the silicic samples shows a wide range ( $X=0.2-0.5)$, which is in fact typical of that seen for suites of titanomagnetites from island arcs (Ermakov et al., 1982). Thus, while a MORB model for the generation of the basalts, and thus implicitly for the Taitao Ridge, is consistent with the petromagnetic observations, the silicic units remain of an enigmatic origin. 
Table 2. Petromagnetic characteristics of samples from Site 862.

\begin{tabular}{|c|c|c|c|c|c|c|c|c|}
\hline $\begin{array}{c}\text { Core. } \\
\text { section. piece }\end{array}$ & $\begin{array}{l}\mathrm{NRM} \\
(\mathrm{A} / \mathrm{m})\end{array}$ & $\begin{array}{l}\mathrm{K}^{*} \mathrm{E} 3 \\
\text { (u. SI) }\end{array}$ & Qn & $\frac{J_{s}}{(A m m / k g)}$ & $J_{r s} / J_{s}$ & $\begin{array}{l}\mathrm{H}_{\mathrm{rs}} \\
(\mathrm{mT})\end{array}$ & $\begin{array}{l}\mathrm{T}_{e} / \mathrm{T}_{\mathrm{ct}} \\
\left({ }^{\circ} \mathrm{C}\right)\end{array}$ & $\mathrm{J}_{\mathrm{st}} / \mathrm{J}_{\mathrm{so}}$ \\
\hline \multicolumn{9}{|l|}{ 141-862B- } \\
\hline IW-1.2 & 0.9 & $\begin{array}{l}5.6 \\
0.8\end{array}$ & $\begin{array}{r}4 \\
54\end{array}$ & $\begin{array}{l}0.38 \\
0.14\end{array}$ & $\begin{array}{l}0.04 \\
0.34\end{array}$ & $\begin{array}{l}20 \\
89\end{array}$ & $\begin{array}{l}400 / 425 \\
350 / 575\end{array}$ & $\begin{array}{l}1.08 \\
3.39\end{array}$ \\
\hline $3 X-1.1$ & 1.8 & $\begin{array}{l}0.8 \\
0.8\end{array}$ & 54 & & 0.38 & $\begin{array}{l}89 \\
68\end{array}$ & & \\
\hline $3 X-1,3$ & 2.1 & $\begin{array}{l}0.8 \\
0.7\end{array}$ & 66 & $\begin{array}{l}0.15 \\
0.19\end{array}$ & 0.26 & $\begin{array}{l}68 \\
86\end{array}$ & & \\
\hline $3 X-1.4$ & 1.7 & 0.7 & 66 & 0.19 & & 86 & & \\
\hline $3 X-1.7$ & 2.1 & 0.9 & 58 & 0.12 & 0.34 & 100 & & \\
\hline $3 X-1,10$ & 2.3 & 1.2 & 49 & 0.19 & 0.38 & 43 & $295 / 575$ & 2.99 \\
\hline $3 X-1,11$ & 1.4 & 0.7 & 53 & 0.08 & 0.28 & 97 & & \\
\hline $3 X-1.12$ & 1.6 & 0.9 & 51 & 0.13 & 0.36 & 90 & & \\
\hline $3 X-1.13$ & 2.3 & 0.7 & 78 & 0.13 & 0.46 & 70 & $335 / 580$ & 3.65 \\
\hline $3 X-1,14$ & 2.6 & 1.1 & 58 & 0.26 & 0.26 & 59 & & \\
\hline $3 X-1.16$ & 3.4 & 1.7 & 50 & 0.18 & 0.18 & 49 & & \\
\hline $3 X-1.17$ & 7.6 & 2.6 & 74 & 0.42 & 0.32 & 21 & $210 / 360$ & 1.72 \\
\hline $3 X-1,18$ & 7.9 & 2.7 & 72 & 0.45 & 0.26 & 19 & $205 / 315$ & 1.54 \\
\hline $4 x-1.1$ & 0.4 & 6.6 & 1 & 0.47 & 0.04 & 20 & $40.5 / 430$ & 1.03 \\
\hline $4 X-1.5$ & 2.7 & 1.8 & 39 & 0.32 & 0.42 & 24 & & \\
\hline $4 X-2,1$ & 6.1 & 8.2 & 19 & 0.92 & 0.18 & 27 & & \\
\hline $4 X-2.2$ & 14.3 & 1.6 & 230 & 0.34 & 0.22 & 20 & & \\
\hline $4 X-2,3$ & 2.5 & 2.8 & 23 & 0.38 & 0.13 & 24 & & \\
\hline $4 X-2,4$ & 6.8 & 5.4 & 31 & 0.46 & 0.13 & 22 & $260 / 565$ & 2.04 \\
\hline $4 X-2.5$ & 5.0 & 4.4 & 28 & 0.54 & 0.14 & 29 & & \\
\hline $4 X-2.7$ & 6.6 & 2.1 & 79 & 0.37 & 0.28 & 26 & $270 / 575$ & 2.43 \\
\hline $4 X-2.8$ & 4.6 & 2.0 & 58 & 0.34 & 0.27 & 27 & & \\
\hline $4 X-2,9$ & 7.6 & 1.8 & 105 & 0.34 & 0.26 & 25 & & \\
\hline $4 X-2,10$ & 5.1 & 1.8 & 70 & 0.38 & 0.32 & 42 & & \\
\hline $4 X-2.11$ & 3.2 & 1.5 & 53 & 0.29 & 0.31 & 31 & & \\
\hline $4 X-2,12$ & 4.8 & 3.0 & 40 & 0.36 & 0.22 & 26 & $275 / 575$ & 2.72 \\
\hline $4 X-2,13$ & 2.7 & 5.0 & 14 & 0.47 & 0.08 & 21 & $210 / 575$ & 1.64 \\
\hline $4 X-2.18$ & 5.5 & 1.6 & 89 & 0.28 & 0.35 & 36 & $260 / 575$ & 2.63 \\
\hline \multicolumn{9}{|l|}{$141-862 \mathrm{C}-$} \\
\hline 4R-1. 1 & 0.1 & 5.3 & 1 & 0.42 & 0.05 & 17 & & \\
\hline $4 \mathrm{R}-\mathrm{I}, 3$ & 0.1 & 4.3 & 1 & 0.28 & 0.04 & 16 & $373 / 390$ & 1.14 \\
\hline 5R-1. 2 & 0.2 & 3.9 & 1 & 0.28 & 0.04 & 19 & & \\
\hline $5 \mathrm{R}-1,3$ & 0.2 & 3.1 & 2 & 0.24 & 0.05 & 16 & $340 / 400$ & 1.20 \\
\hline
\end{tabular}

Notes: $\mathrm{NRM}=$ natural remanent magnetization: $\mathrm{K}=$ magnetic susceptibility: $Q \mathrm{n}=$ Koenigsberger ratio: $\mathrm{J}_{\mathrm{s}}=$ saturation magnetization; $\mathrm{J}_{\mathrm{r}}=\mathrm{remanent}_{\mathrm{saturation}}$ magnetization: $\mathrm{H}_{\mathrm{sr}}=$ remanent coercive force: $\mathrm{T}_{\mathrm{c}}=$ Curie point: $\mathrm{T}_{\mathrm{c}}=$ Curie point after heating to $600^{\circ} \mathrm{C}: \mathrm{J}_{\mathrm{so}}, \mathrm{J}_{\mathrm{s}}=\mathrm{J}_{\mathrm{s}}$ before and after heating.

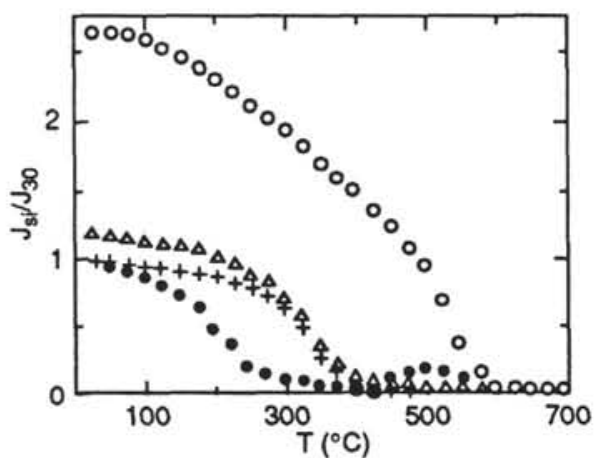

Figure 4. Thermomagnetic analyses of magmatic rocks from the Taitao Ridge. Crosses $=$ first heating, open triangles $=$ second heating; Sample 141-862C $4 \mathrm{R}-1$, Piece 3 (silicic). Filled circles $=$ first heating, open circles $=$ second heating; Sample 141-862B-4X-2, Piece 18 (basaltic).

Third, petromagnetic data suggest that significant low-temperature oxidation (leading to the formation of titanomaghemite) is typical only for titanomagnetites contained within the Taitao Ridge basalt samples. Formation of low temperature oxidation products exclusively in the basalts suggests significantly different environments of alteration between the basalts and the acidic rocks (excluding compositional influences on alteration).

The systematic differences in magnetic characteristics reported here among the two basalt groups are clearly a product of position within the flow units. The glassy to hyalocrystalline, vesicular, and spherulitic textures of Group 1 are undoubtedly associated with the recovered marginal parts of submarine flows. The subophitic textures of Group 2 basalt samples are representative of the slower-cooling interiors of the flows. The distinctive magnetic characteristics from these two textural types support the argument that the interior and

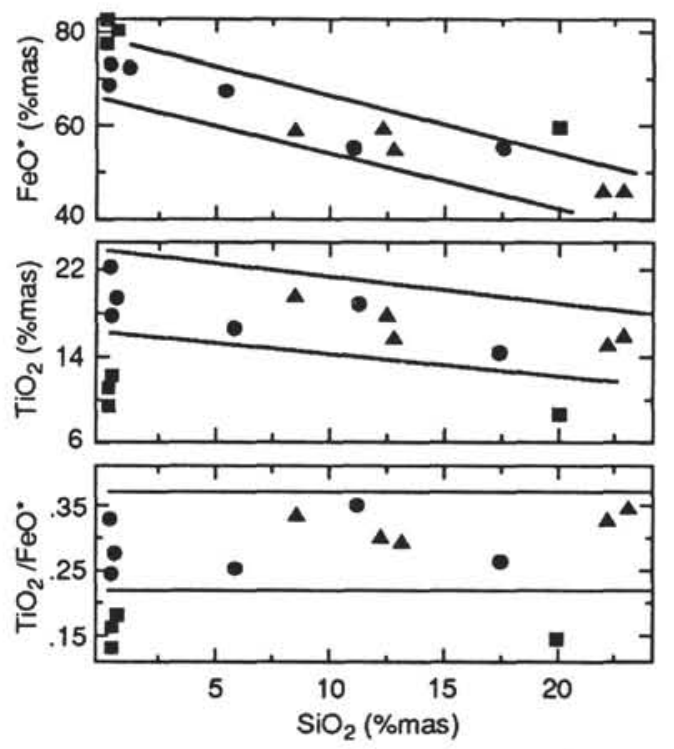

Figure 5. $\mathrm{FeO}^{*}, \mathrm{TiO}_{2}$, and their ratio vs. $\mathrm{SiO}_{2}$ for titanomagnetites and titanomaghemites of magmatic rocks from Taitao Ridge. For legend see Figure 2.

exterior of these units evolved along quite separate petromagnetic paths. Both primary and secondary processes that have given rise to the magnetic carriers within the texturally distinct parts of these flows lead to distinct trends in magnetic intensities, susceptibilities and the thermal characteristics of the remanence.

Both the inferred original and the secondary ferrimagnetic phases have relatively low Curie temperatures. Estimates of the Curie points for the original titanomagnetite are only $170^{\circ}-190^{\circ} \mathrm{C}$, which suggest 
Table 3. Compositions of opaque minerals in igneous samples from Site 862 .

\begin{tabular}{|c|c|c|c|c|c|c|}
\hline \multirow[b]{2}{*}{ Hole, core, section: } & \multicolumn{6}{|c|}{ Acidic rocks } \\
\hline & $862 \mathrm{~B}-1 \mathrm{~W}-1$ & $862 \mathrm{~B}-4 \mathrm{X}-1$ & $862 B-4 X-1$ & $862 C-4 R-1$ & $862 C-4 R-1$ & $862 C-5 R-1$ \\
\hline Piece: & 2 & 1 & 1 & 3 & 3 & 3 \\
\hline $\mathrm{SiO}_{2}$ & 19.93 & 0.06 & 0.04 & 0.1 & - & - \\
\hline $\mathrm{TiO}_{2}^{-}$ & 7.91 & 12.74 & 12.86 & 9.69 & 47.52 & 48.47 \\
\hline $\mathrm{Al}_{2} \mathrm{O}_{3}$ & 3.93 & 2.04 & 1.97 & 1.69 & 0.13 & 0.11 \\
\hline $\mathrm{FeO}$ & 58.45 & 77.1 & 78.78 & 79.82 & 48.03 & 46.86 \\
\hline $\mathrm{MgO}$ & 1.46 & 0.98 & 0.95 & 0.82 & 1.97 & 2.28 \\
\hline $\mathrm{MnO}$ & 0.19 & 0.15 & 0.14 & 0.11 & 0.31 & 0.31 \\
\hline $\mathrm{Cr}_{2} \mathrm{O}_{3}$ & 0.025 & 0.041 & 0.045 & 0.07 & 0.044 & 0.041 \\
\hline $\mathrm{C}_{3} \mathrm{O}_{5}$ & 0.206 & 0.861 & 0.803 & 0.798 & 0.147 & 0.026 \\
\hline $\mathrm{NiO}$ & 0.009 & - & - & - & - & - \\
\hline $\mathrm{CuO}$ & 0.001 & - & - & 0.004 & 0.001 & - \\
\hline Total & 92.11 & 93.97 & 95.59 & 93.1 & 98.15 & 98.1 \\
\hline $\mathrm{T}_{c}\left(\mathrm{TiO}_{2}\right)$ & - & 345 & 345 & 430 & $\mathrm{IIm}$ & $\mathrm{llm}$ \\
\hline $\mathrm{T}_{c}(\mathrm{Ti} / \mathrm{Fe})$ & 375 & 330 & 335 & 400 & & \\
\hline \multicolumn{7}{|l|}{ Mean for acid rocks } \\
\hline $\mathrm{T}_{c}\left(\mathrm{TiO}_{2}\right)$ & 360 & & & & & \\
\hline $\mathrm{T}_{c}(\mathrm{Ti} / \mathrm{Fe})$ & 350 & & & & & \\
\hline
\end{tabular}

that these rocks would be easily remagnetized when subjected to additional sources of heat. Curie points of the secondary phases are also relatively low, but extend upwards to $350^{\circ} \mathrm{C}$. These results suggest that if the basaltic crust of Taitao Ridge were subjected to a second phase of volcanism, or perhaps to underplating by a southward extension of the currently subducting segment of the Chile Rise to the north, it could easily be remagnetized. An inversion of titanomaghemite to titanomagnetite would also be possible, given appropriate oxidation conditions. Previous modelling of the marine data covering the convergence zone for young oceanic crust in this region (Leslie, 1986) suggested extremely steep subduction angles in order to account for a landward fall off in the observed intensities of the magnetic anomalies. The geothermal gradients observed on Leg 141 (up to $100^{\circ} \mathrm{C} / \mathrm{km}$ ) when combined with the lower temperature Curie points (for at least the residual primary titanomagnetites) could explain this abrupt landward decrease in the observed intensities of magnetic anomalies. The abrupt changes in the petromagnetic properties of young oceanic crust as it enters a subduction zone could represent an additional distinctive petromagnetic effect of ridge subduction.

\section{CONCLUSIONS}

1. The geochemical and petromagnetic data that have been reported here reinforce the initial suggestion that the magmatism on the Taitao Ridge is bimodal. This also supports an argument for two distinct sources for the basaltic and silicic magmas.

2. The two groups of basalts with contrasting textures from Site 862 have petromagnetic properties consistent with drilling having recovered fragments of the same flows, but with the two groups of fragments represent two different sets of cooling and secondary alteration conditions within the flows. The observed correlation of textures and magnetic properties for the Taitao Ridge basalts are typical of submarine pillow basalts generated in MORB environs.

3. The estimated Curie temperatures for the ferrimagnetic phases within the basalt groups are relatively low. This suggests that oceanic crust subjected to elevated forearc thermal conditions (such as are observed in this area) could be easily remagnetized during obduction or underthrusting.

\section{ACKNOWLEDGMENTS}

We thank Monica Sweitzer for helpful assistance aboard the JOIDES Resolution during Leg 141. We also thank Simon Allerton, Bob Musgrave, and an anonymous reviewer for their reviews and comments.

\section{REFERENCES}

Behrmann, J.H., Lewis, S.D., Musgrave, R.J., et al., 1992. Proc. ODP, Init. Repts., 141: College Station, TX (Ocean Drilling Program).

Didenko, A.N., 1990. The study of compositions of titanomagnetites from basalts of transform fault Green Cap: Central Atlantic. Rep. Acad. Sci. USSR, 309:667-669.

Didenko, A.N., and Tikhonov, L.V., 1991. Petromagnetic study of basalts. In Pushcharovsky, Yu.M.(Ed.), The Structure of Fault Doll-Drams: Moscow (Nauka). (in Russian)

Ermakov, V.A., Pechersky, D.M., and Sharonova, Z.V., 1982. Petromagnetic features of Quaternary volcanic rocks of Central Kamchatka. Izv. Akad. Nauk SSSR, Ser. Earth's Physics, 12:76-87.

Ewart, A., 1982. The mineralogy and petrology of Tertiary-Recent orogenic rocks: with special reference to the andesitic-basaltic compositional range. In Thorpe, R.S. (Ed.), Andesites: Orogenic Andesites and Related Rocks: New York (Wiley), 25-87.

Forsythe, R.D., Nelson, E.P., Carr, M.J., Kaeding, M.E., Herve, M., Mpodozis, C., Soffia, J.M., and Harambour, S., 1986. Pliocene near-trench magmatism in southern Chile: a possible manifestation of ridge collision. Geology, $14: 23-27$.

Kobayashi, K., and Fuller, M., 1967. Vibration magnetometer. In Collinson, D.W., Creer, K.M., and Runcorn, S.K. (Eds.), Methods in Paleomagnetism: New York (Elsevier), 450-456.

Leslie, R.B., 1986. Cenozoic tectonics of southern Chile: triple junction migration, ridge subduction, and forearc evolution [Ph.D. thesis]. Columbia Univ., New York.

Miyashiro, A., 1975. Classification, characteristics and origin of ophiolites. I. Geol., 83:249-281.

Nelson, E.P., Forsythe, R.D., Diemer, J.A., and Urbino, O., 1994. Taitao Ophiolite: a ridge collision ophiolite in the fore arc of southern Chile $\left(46^{\circ} \mathrm{S}\right)$. Rev. Geol. Chile, 20:137-165.

Pechersky, D.M., Bagin, V.I., Brodskaya, S.Yu., and Sharonova, Z.V., 1975. Magnetism and Conditions of Origin in Extrusive Rocks: Moscow (Nauka). (in Russian)

Pechersky, D.M., and Tikhonov, L.V., 1983. Petromagnetic peculiarities of basalts from Atlantic and Pacific oceans. Izv. Akad. Nauk SSSR, Ser. Earth's Physics, 4:79-90.

Seyfert, C.K., 1991. Plate tectonics. Mantle plumes and origin of magmas. In Seyfert, C.K. (Ed.), Structural Geology and Plate Tectonics: Moscow (Mir), 3:72-156. (in Russian)

Sholpo, L.Ye., 1976. Petromagnetic Solutions to Geological Problems: Leningrad (Nedra). (in Russian)

Abbreviations for names of organizations and publications in ODP reference lists follow the style given in Chemical Abstracts Service Source Index (published by American Chemical Society).

Date of initial receipt: 20 September 1993

Date of acceptance: 14 December 1994

Ms 141SR-014 
PETROMAGNETIC STUDY, SITE 862

Table 3 (continued).

\begin{tabular}{|c|c|c|c|c|c|c|c|c|c|c|c|}
\hline \multirow[b]{2}{*}{ Hole, core, section: } & \multicolumn{11}{|c|}{ Basaltic rocks } \\
\hline & $862 \mathrm{~B}-3 \mathrm{X}-1$ & $862 B-3 X-1$ & $862 \mathrm{~B}-3 \mathrm{X}-1$ & $862 B-3 X-1$ & $862 B-3 X-1$ & $862 B-4 X-2$ & $862 B-4 X-2$ & $862 B-4 X-2$ & $862 B-4 X-2$ & $862 \mathrm{~B}-4 \mathrm{X}-2$ & $862 B-4 X-2$ \\
\hline Piece: & 10 & 17 & 17 & 18 & 18 & 4 & 4 & 12 & 13 & 13 & 18 \\
\hline $\mathrm{SiO}_{2}$ & 22.29 & 22.86 & 12.58 & 8.51 & 12.78 & 0.36 & 0.35 & 17.37 & 5.80 & 0.63 & 10.98 \\
\hline $\mathrm{TiO}_{2}^{-}$ & 14.58 & 15.42 & 16.83 & 19.17 & 16.13 & 22.45 & 17.63 & 13.93 & 16.61 & 19.42 & 18.94 \\
\hline $\mathrm{Al}_{2} \mathrm{O}_{3}$ & 2.94 & 7.41 & 2.9 & 1.85 & 3.78 & 1.43 & 1.74 & 4.49 & 1.91 & 1.67 & 3.19 \\
\hline $\mathrm{FeO}$ & 45.18 & 45.19 & 57.53 & 58.14 & 55.19 & 68.02 & 71.98 & 53.02 & 66.12 & 71.35 & 54.59 \\
\hline $\mathrm{MgO}$ & 6.78 & 2.13 & 2.84 & 1.85 & 5.24 & 1.04 & 1.35 & 2.53 & 1.87 & 1.85 & 2.88 \\
\hline $\mathrm{MnO}$ & 0.38 & 0.38 & 0.38 & 0.51 & 0.43 & 0.39 & 0.36 & 0.37 & 0.38 & 0.51 & 0.48 \\
\hline $\mathrm{Cr}_{2} \mathrm{O}_{3}$ & 0.022 & 0.031 & 0.022 & 0.035 & 0.023 & 0.052 & 0.031 & 0.021 & 0.021 & 0.021 & 0.047 \\
\hline $\mathrm{V}_{2} \mathrm{O}_{5}$ & 0.181 & 0.233 & 0.248 & 0.199 & 0.365 & 0.428 & 0.609 & 0.169 & 0.277 & 0.323 & 0.356 \\
\hline $\mathrm{NiO}$ & 0.004 & - & 0.02 & - & - & - & - & - & - & - & - \\
\hline $\mathrm{CuO}$ & 0.029 & 0.037 & 0.032 & 0.021 & 0.028 & 0.022 & 0.021 & 0.026 & 0.028 & 0.022 & 0.024 \\
\hline Total & 92.39 & 93.69 & 93.48 & 90.29 & 93.97 & 94.19 & 94.07 & 91.93 & 93.02 & 95.8 & 91.49 \\
\hline $\mathrm{T}_{c}\left(\mathrm{TiO}_{2}\right)$ & - & - & - & - & - & 150 & 240 & - & - & 200 & - \\
\hline $\mathrm{T}_{s}(\mathrm{Ti} / \mathrm{Fe})$ & 120 & 100 & 150 & 100 & 150 & 110 & 210 & 190 & 210 & 180 & 95 \\
\hline \multicolumn{12}{|l|}{ Mean for basalts } \\
\hline $\mathrm{T}_{3}\left(\mathrm{TiO}_{2}\right)$ & & & & 175 & & & & & & & \\
\hline $\mathrm{T}_{0}\left(\mathrm{Ti} / \mathrm{Fe}^{\prime}\right)$ & & & & 150 & & & & & & & \\
\hline
\end{tabular}

Note: Contents of oxides are in wt $\% . \mathrm{T}_{\mathrm{c}}=$ Curie point calculated on the basis of the concentration of $\mathrm{TiO}_{2}$ and $\mathrm{TiO}_{2} / \mathrm{FeO}^{2}$. Mean values for acidic rocks and basalts calculated from linear regression against proportion of silica in the analysis (see Fig. 5). Ilm = ilmenite. 